\title{
Claro Enigma - Análise do discurso: reconfiguração do ethos em e no Legado de Carlos Drummond de Andrade
}

\author{
Luisiana Ferreira Moura \\ Mestranda em Língua Portuguesa/PUC-SP
}

RESUMO: Carlos Drummond de Andrade possui características singulares cuja obra revela as relações entre indivíduo e sociedade, fundamentando no fazer poético uma análise social e existencial dos homens. Assim, tendo em vista a construção de uma identidade enunciativa projetada num ethos que legitimou o enunciador dentro de um posicionamento político-social, especialmente nas produções da década de 40, e que tal posicionamento, já consolidado, é sensivelmente reconfigurado em Claro Enigma, de 1951, analisamos o poema Legado que compõe esta obra, e aqui apreendido como discurso, numa perspectiva enunciativo-discursiva sob orientação teórico-metodológica da Análise do Discurso de linha francesa, conforme estudos desenvolvidos por Maingueneau e observamos que a reconfiguração do ethos se faz evidente no cotejo com formações discursas anteriores, legitimadas por uma comunidade literária e pela imagem projetada do autor, o que permitiu reflexões de como as condições sóciohistóricas de produção influenciavam sensivelmente autores que se voltavam ora para a denúncia social e resistência política, ora para reflexões existenciais sobre o homem, a sociedade e a vida.

PALAVRAS-CHAVE: Discurso; Literatura; Autoralidade; Ethos Discursivo. 